\title{
Amorphous LiSiON Thin Film Electrolyte for All-solid-state Thin Film Lithium Battery
}

\author{
XIA Qiuying, SUN Shuo, ZAN Feng, XU Jing, XIA Hui
}

(School of Materials Science and Engineering, Nanjing University of Science and Technology, Nanjing 210094, China)

\begin{abstract}
All-solid-state thin film lithium battery (TFLB) is regarded as the ideal power source for microelectronic devices. However, the relatively low ionic conductivity of amorphous solid-state electrolyte limits the improvement of electrochemical performance for TFLB. In this work, amorphous lithium silicon oxynitride (LiSiON) thin films are prepared by magnetron sputtering as solid-state electrolyte for TFLB. With optimized deposition condition, the LiSiON thin film exhibits a high ionic conductivity of $6.3 \times 10^{-6} \mathrm{~S} \cdot \mathrm{cm}^{-1}$ at room temperature and a wide voltage window over $5 \mathrm{~V}$, making it a suitable thin film electrolyte for TFLB. A $\mathrm{MoO}_{3} / \mathrm{LiSiON} / \mathrm{Li}$ TFLB is constructed based on the LiSiON thin film electrolyte with large specific capacity $\left(282 \mathrm{mAh} \cdot \mathrm{g}^{-1}\right.$ at $\left.50 \mathrm{~mA} \cdot \mathrm{g}^{-1}\right)$, good rate capability $\left(50 \mathrm{mAh} \cdot \mathrm{g}^{-1}\right.$ at $\left.800 \mathrm{~mA} \cdot \mathrm{g}^{-1}\right)$, and acceptable cycle life $(78.1 \%$ capacity retention after 200 cycles), demonstrating the feasibility of this electrolyte for practical applications.
\end{abstract}

Key words: LiSiON; thin film electrolyte; all-solid-state lithium battery; thin film battery

The rapid development of microelectronics industry, such as micro-electromechanical systems (MEMS), micro sensors, intelligent cards, and implantable micro medical devices, leads to increasing demands for integrated micro-sized energy storage ${ }^{[1-2]}$. Among the available battery technologies, all-solid-state thin film lithium battery (TFLB) is considered as the ideal power source for microelectronic devices due to their high safety, small size, power-on-chip design, long cycle life, and low self-discharge rate. As one of the key components in TFLB, solid-state thin film electrolyte plays a vital role in determining the properties of TFLB $^{[3]}$. Therefore, developing high-performance solid-state thin film electrolyte is always an important goal for the development of TFLB. At present, the most widely used electrolyte in TFLB is amorphous lithium phosphorus oxynitride (LiPON), which has moderate ionic conductivity $\left(2 \times 10^{-6} \mathrm{~S} \cdot \mathrm{cm}^{-1}\right)$, low electronic conductivity $\left(\sim 10^{-14} \mathrm{~S} \cdot \mathrm{cm}^{-1}\right)$, wide voltage window $(\sim 5.5 \mathrm{~V})$, and good contact stability with lithium ${ }^{[4-5]}$. However, its ionic conductivity is relatively low, which impedes the future development of high power TFLB for the upcoming era of the Internet of Things (IoT) ${ }^{[6]}$. Thus, it is urgent to develop new thin film electrolytes with increased ionic conductivity, as well as large voltage window and good contact stability with lithium for next-generation TFLB.

Among various inorganic solid-state electrolyte materials, the $\mathrm{Li}_{2} \mathrm{O}-\mathrm{SiO}_{2}$ solid solution system and their deuterogenic phases were identified as potential thin film electrolytes due to their fast three-dimensional lithium conduction channels ${ }^{[7]}$. For example, Chen, et al. ${ }^{[8]}$ reported that $\mathrm{Al}$ substituted $\mathrm{Li}_{4.4} \mathrm{Al}_{0.4} \mathrm{Si}_{0.6} \mathrm{O}_{4}-0.3 \mathrm{Li}_{2} \mathrm{O}$ solid electrolyte has a high ionic conductivity of $5.4 \times 10^{-3} \mathrm{~S} \cdot \mathrm{cm}^{-1}$ at $200{ }^{\circ} \mathrm{C}$. Adnan, et al. ${ }^{[9]}$ found that $\mathrm{Li}_{4} \mathrm{Sn}_{0.02} \mathrm{Si}_{0.98} \mathrm{O}_{4}$ compound possesses a maximum conductivity value of $3.07 \times 10^{-5} \mathrm{~S} \cdot \mathrm{cm}^{-1}$ at ambient temperature. However, previous works on $\mathrm{Li}_{2} \mathrm{O}-\mathrm{SiO}_{2}$ electrolyte systems mostly focused on powder materials with high crystallinity, while very limited work was reported on their amorphous thin film counterparts for TFLB. Since TFLB is typically constructed by depositing thin films of cathode, electrolyte and anode layer by layer, the electrolyte film is required to be prepared at relatively low temperature to avoid the unfavorable interactions between the cathode and electrolyte, which result in crack and short circuit of the TFLB ${ }^{[1-2]}$. Thus, developing $\mathrm{Li}_{2} \mathrm{O}-\mathrm{SiO}_{2}$ electrolyte with amorphous feature prepared at low temperature is important for TFLB.

Received date: 2021-03-06; Revised date: 2021-05-06; Published online: 2021-06-10

Foundation item: National Key R\&D Program of China (2020YFB2007400); National Natural Science Foundation of China (51802159, 51972174, 52002183)

Biography: XIA Qiuying (1991-), male, PhD. E-mail: qiuyingxia@njust.edu.cn

夏求应(1991-), 男, 博士. E-mail: qiuyingxia@njust.edu.cn

Corresponding author: XIA Hui, professor. E-mail: xiahui@njust.edu.cn 夏 晖, 教授. E-mail: xiahui@njust.edu.cn 
Although recent work ${ }^{[6]}$ shows that a high lithium ionic conductivity of $2.06 \times 10^{-5} \mathrm{~S} \cdot \mathrm{cm}^{-1}$ can be obtained by amorphous Li-Si-P-O-N thin film, its contact stability with the electrodes and electrochemical stability in TFLB have yet to be investigated. Therefore, it is critically important to develop high-performance $\mathrm{Li}_{2} \mathrm{O}-\mathrm{SiO}_{2}$ based thin film electrolyte and demonstrate its actual application in TFLB.

In this work, amorphous lithium silicon oxynitride (LiSiON) thin film was prepared by radio frequency (RF) magnetron sputtering at room temperature and investigated as solid-state electrolyte for TFLB. The sputtering power and the flow of $\mathrm{N}_{2} / \mathrm{Ar}$ working gas were optimized to obtain the best deposition condition for the LiSiON thin film. Moreover, to demonstrate the applicability of the optimized LiSiON electrolyte for TFLB, a $\mathrm{MoO}_{3} / \mathrm{LiSiON} / \mathrm{Li}$ full cell was constructed and its electrochemical performance was systematically investigated.

\section{Experimental}

\subsection{Preparation of LiSiON thin films}

LiSiON thin films were prepared by RF magnetron sputtering (Kurt J. Lesker) using a $\mathrm{Li}_{2} \mathrm{SiO}_{3}$ target (76.2 $\mathrm{mm}$ in diameter) at room temperature for $12 \mathrm{~h}$. Before deposition, the pressure of the chamber was reduced to less than $1 \times 10^{-5} \mathrm{~Pa}$. The distance from target to substrate was $10 \mathrm{~cm}$. The samples deposited under RF power of 80,100 , and $120 \mathrm{~W}$ at the flow of $90 \mathrm{sccm} \mathrm{N}_{2}$ are marked as sample LiSiON-80N9, LiSiON-100N9, and LiSiON-120N9, respectively. And the samples deposited under RF power of $100 \mathrm{~W}$ at the flow of $90 \mathrm{sccm}$ $\mathrm{N}_{2}$ and $10 \mathrm{sccm} \mathrm{Ar}, 90 \mathrm{sccm} \mathrm{N} \mathrm{N}_{2}$ and $50 \mathrm{sccm} \mathrm{Ar}, 50 \mathrm{sccm}$ $\mathrm{N}_{2}$ and $50 \mathrm{sccm}$ Ar are marked as sample LiSiON100N9A1, LiSiON-100N9A5, and LiSiON-100N5A5, respectively.

\subsection{Preparation of $\mathrm{MoO}_{3} / \mathrm{LiSiON} / \mathrm{Li}$ TFLB}

$\mathrm{MoO}_{3}$ film was prepared by direct current (DC) reactive magnetron sputtering (Kurt J. Lesker) using a pure metal Mo target ( $76.2 \mathrm{~mm}$ in diameter) according to our previous report ${ }^{[10]}$. The distance from target to substrate was $10 \mathrm{~cm}$, and DC sputtering power was $60 \mathrm{~W}$. The deposition was performed at the substrate temperature of $100{ }^{\circ} \mathrm{C}$ for $4 \mathrm{~h}$ at the flow of $40 \mathrm{sccm} \mathrm{Ar}$ and $10 \mathrm{sccm} \mathrm{O}_{2}$, followed by an in-situ annealing treatment at $450{ }^{\circ} \mathrm{C}$ for $1 \mathrm{~h}$. LiSiON-100N9A1 was then deposited on the $\mathrm{MoO}_{3}$ film as electrolyte. After that, a metallic lithium film of about $2 \mu \mathrm{m}$ in thickness was deposited on the LiSiON film by vacuum thermal evaporation (Kurt J. Lesker). The final fabrication step involved the deposition of $\mathrm{Cu}$ current collector and the encapsulation process.

\subsection{Material characterization}

The crystal structures of the samples were characterized by X-ray diffraction (XRD, Bruker D8 Advance). The morphologies and microstructures of the samples were characterized by field emission scanning electron microscope (FESEM, FEI Quanta 250F) equipped with energy-dispersive X-ray spectroscopy (EDS). The elemental compositions of the samples were analyzed by inductively coupled plasma mass spectrometry (ICP-MS, Agilent 7700X). The chemical composition and bonding information of the samples were measured by X-ray photoelectron spectroscopy (XPS, Escalab 250XI, Thermo Scientific).

\subsection{Electrochemical measurements}

The ionic conductivity of the LiSiON thin film electrolyte was measured using a sandwiched structure of $\mathrm{Pt} / \mathrm{LiSiON} / \mathrm{Pt}$. The electrochemical impedance spectroscopy (EIS) (from $1000 \mathrm{kHz}$ to $0.1 \mathrm{~Hz}$ with potential amplitude of $5 \mathrm{mV}$ ) and cyclic voltammetry (CV) measurements of the samples were carried out on the Biologic VMP3 electrochemical workstation. Galvanostatic charge/discharge (GCD) measurement of the $\mathrm{MoO}_{3} / \mathrm{LiSiON} / \mathrm{Li}$ TFLB was carried out using a Neware BTS4000 battery system in an argon-filled glove box at room temperature. A Sartorius Analytical Balance (CPA225D, with resolution of $10 \mu \mathrm{g}$ ) was used to determine the electrode mass loading, and the mass loading of the $\mathrm{MoO}_{3}$ film is about $0.4 \mathrm{mg} \cdot \mathrm{cm}^{-2}$.

\section{Results and discussion}

As shown in the optical image inserted in Fig. 1(a), a $\mathrm{Li}_{2} \mathrm{SiO}_{3}$ target was employed to prepare LiSiON thin film. The XRD result in Fig. 1(a) reveals that the target is composed of the major $\mathrm{Li}_{2} \mathrm{SiO}_{3}$ (JCPDS 83-1517) phase and minor $\mathrm{SiO}_{2}$ phase. ICP-MS measurement indicates that the atomic ratio of $\mathrm{Li}: \mathrm{Si}$ is about $1.79: 1$ in the target. Transparent amorphous thin film was obtained for the typical sample LiSiON-100N9A1 after sputtering the target (Fig. 1(b)). The thickness of the typical sample LiSiON-100N9A1 measured from the cross-section FESEM image in Fig. 1(c) is about $1.2 \mu \mathrm{m}$, indicating a growth rate of about $100 \mathrm{~nm} \cdot \mathrm{h}^{-1}$ under this condition. As shown in the top-view FESEM image in Fig. 1(d), the surface of the LiSiON thin film is very smooth and dense without cracks or pinholes, making it a suitable solid electrolyte for TFLB to avoid shortcut and safety problem.

XPS analysis was carried out to investigate the chemical composition and bonding information of the $\mathrm{Li}_{2} \mathrm{SiO}_{3}$ 

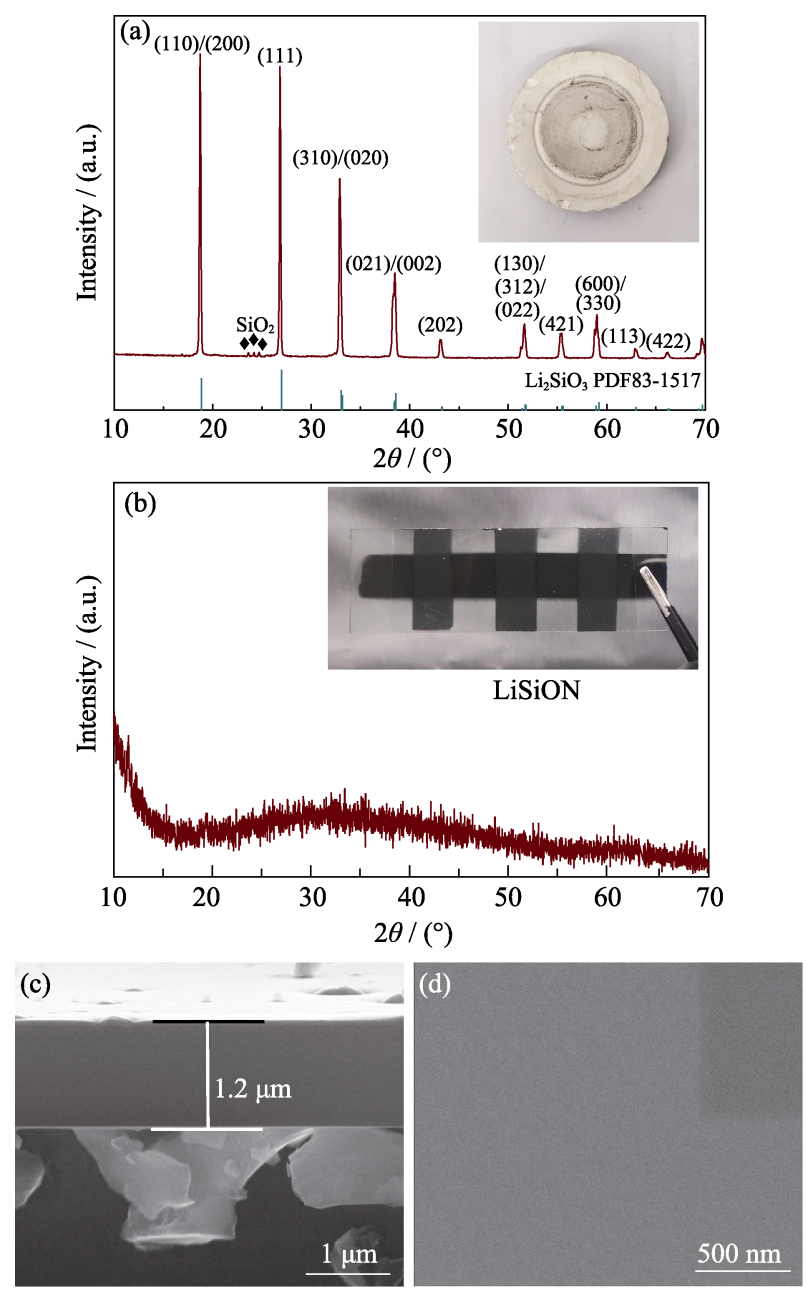

Fig. 1 (a) XRD pattern and optical image of the $\mathrm{Li}_{2} \mathrm{SiO}_{3}$ target; (b) XRD pattern and optical image of typical sample LiSiON100N9A1; (c) Cross-section and (d) top-view FESEM images of the typical sample LiSiON-100N9A1

target and typical sample LiSiON-100N9A1. The XPS survey scan spectra in Fig. 2(a) reveal the presence of $\mathrm{Li}$, $\mathrm{Si}$, and $\mathrm{O}$ elements in the $\mathrm{Li}_{2} \mathrm{SiO}_{3}$ target and the introduction of $\mathrm{N}$ element in the LiSiON thin film. The atomic ratio of $\mathrm{N}: \mathrm{Si}$ in $\mathrm{LiSiON}$ thin film is about $0.33: 1$ according to the XPS result. Combining with the corresponding atomic ratio $(1.51: 1)$ obtained by the ICP-MS measurement, the stoichiometry of the typical sample LiSiON-100N9A1 is determined to be $\mathrm{Li}_{1.51} \mathrm{SiO}_{2.26} \mathrm{~N}_{0.33}$. Compared with the single $\mathrm{Si}-\mathrm{Si}$ $(103.2 \mathrm{eV})$ peak in the Si2p core-level XPS spectrum of the $\mathrm{Li}_{2} \mathrm{SiO}_{3}$ target (Fig. 2(b)), additional Si-N (101.6 eV) peak can be observed from the LiSiON thin film, suggesting the occurrence of nitridation in $\mathrm{LiSiON}^{[11-12]}$. The O1s core-level XPS spectrum of $\mathrm{Li}_{2} \mathrm{SiO}_{3}$ target in Fig. 2(c) shows two bonding environments: $531.5 \mathrm{eV}$ originated from $\mathrm{SiO}_{x}$ and $528.8 \mathrm{eV}$ assigned to $\mathrm{Li}_{2} \mathrm{O}$. After deposition, additional component emerged at $530.2 \mathrm{eV}$ can be observed with LiSiON thin film, which can be assigned to nonbridging oxygen $\left(\mathrm{O}_{\mathrm{n}}\right)$ in sili- cate $^{[13-14]}$. The N1s core-level XPS spectrum of LiSiON thin film in Fig. 2(d) can be deconvoluted into three peaks, including $398.2 \mathrm{eV}$ for $\mathrm{Si}-\mathrm{N}$ bonding, $396.4 \mathrm{eV}$ for $\mathrm{Li}_{3} \mathrm{~N}$, and $403.8 \mathrm{eV}$ for nitrite species $\mathrm{NO}_{2}^{-}$, further confirming the incorporation of $\mathrm{N}$ into the LiSiON network $^{[14-16]}$. As schematically illustrated in Fig. 2(e), the incorporation of $\mathrm{N}$ into the LiSiON network can form more cross-linked structure, which is beneficial for fast lithium ion conduction ${ }^{[6,17]}$.

To optimize the ionic conductivity and electrochemical stability of the LiSiON thin films, various LiSiON thin films deposited at different sputtering powers, and working gas flows were compared in terms of their ionic conductivities and voltage windows. The room-temperature Nyquist plots of the LiSiON thin films are depicted in Fig. 3(a), and the corresponding Pt/LiSiON/Pt sandwich structure and equivalent circuit are shown in Fig. 3(b). As observed, the Nyquist plots exhibit a single semicircle and dielectric capacitance tail, which is characteristic of thin-film conducting dielectric with bulk relaxation process sandwiched between blocking contacts ${ }^{[17]}$. The ionic conductivities $\left(\sigma_{\mathrm{i}}\right)$ of the LiSiON thin films can be calculated by using Eq. (1).

$$
\sigma_{\mathrm{i}}=d /(R A)
$$

where $d$ is the film thickness, $A$ is the effective area (about $1 \mathrm{~cm}^{2}$ ), and $R$ is the film resistance estimated from the measured Nyquist plot. The calculated ionic conductivities for these LiSiON thin films are compared in Table 1. As observed, the ionic conductivity of the LiSiON thin film deposited at a constant flow of $90 \mathrm{sccm}$ $\mathrm{N}_{2}$ increases with the increasing sputtering power from $80 \mathrm{~W}$ to $100 \mathrm{~W}$, then decreases when the sputtering power is further elevated to $120 \mathrm{~W}$, which is similar to previous report on LiPON electrolyte ${ }^{[18]}$. An obvious increment in the ionic conductivities can be observed when the $\mathrm{N}_{2}$ ratio in the working gas under a constant sputtering power of $100 \mathrm{~W}$ is promoted, which can be attributed to the increased amount of incorporated nitrogen in the LiSiON with more favorable environment for lithium ion motion ${ }^{[5,18]}$. Noticeably, the sample LiSiON100N9 and LiSiON-100N9A1 show the highest ionic conductivities of $7.1 \times 10^{-6}$ and $6.3 \times 10^{-6} \mathrm{~S} \cdot \mathrm{cm}^{-1}$, respectively, which are obviously higher than the well-known LiPON $\left(\sim 2 \times 10^{-6} \mathrm{~S} \cdot \mathrm{cm}^{-1}\right)$, previous reported amorphous $\mathrm{LiNbO}_{3}\left(\sim 1 \times 10^{-6} \mathrm{~S} \cdot \mathrm{cm}^{-1}\right)^{[19]}$, LiBON $\left(2.3 \times 10^{-6} \mathrm{~S} \cdot \mathrm{cm}^{-1}\right)^{[20]}$, Li-V-Si-O $\left(\sim 1 \times 10^{-6} \mathrm{~S} \cdot \mathrm{cm}^{-1}\right)^{[21]}$, Li-La-Zr-O $\left(4 \times 10^{-7} \mathrm{~S} \cdot \mathrm{cm}^{-1}\right)^{[22]}$, and Li-Si-P-O $\left(1.6 \times 10^{-6} \mathrm{~S} \cdot \mathrm{cm}^{-1}\right)^{[23]}$ electrolyte films, revealing that the amorphous LiSiON thin film is a competitive candidate as electrolyte for TFLB. The high ion conductivity of the LiSiON thin film can be attributed to the incorporation of $\mathrm{N}$ into the thin film and the formation of $\mathrm{Si}-\mathrm{N}$ bonds instead of $\mathrm{Si}-\mathrm{O}$ bonds, 
leading to a more reticulated anionic network for the facile lithium ion mobility ${ }^{[17,24]}$. The electrochemical stable voltage windows of the LiSiON thin films were evaluated by $\mathrm{CV}$ measurement at a scan rate of $5 \mathrm{mV} \cdot \mathrm{s}^{-1}$ with voltage up to $5.5 \mathrm{~V}$. It should be pointed out that the impact of deposition condition on the voltage window of
LiSiON films varies, which cannot be explained by a clear mechanism currently since there are no relevant researches in previous reports about thin film electrolyte ${ }^{[18,24-25]}$. Nevertheless, as compared in Fig. 3(c) and Table 1, the sample LiSiON-100N9A1 and LiSiON$100 \mathrm{~N} 5 \mathrm{~A} 5$ show the broadest voltage windows of $\sim 5.0$ and
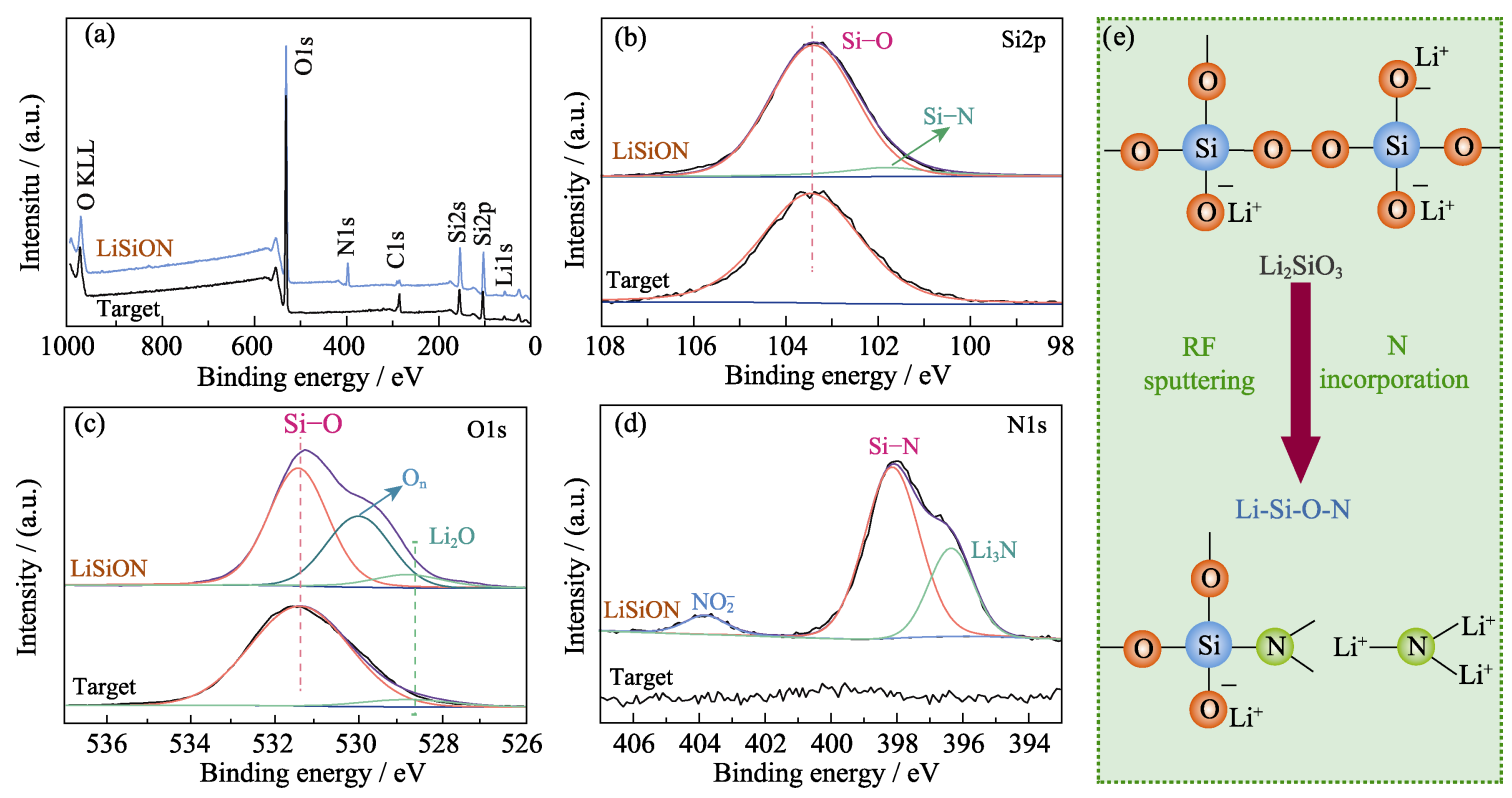

Fig. 2 (a) Survey-scan, (b) Si2p core-level, (c) O1s core-level, and (d) N1s core-level XPS spectra of $\mathrm{Li}_{2} \mathrm{SiO}_{3}$ target and typical sample LiSiON-100N9A1; (e) Schematic illustration of the partial structure change from $\mathrm{Li}_{2} \mathrm{SiO}_{3}$ to $\mathrm{LiSiON}$ with the incorporation of $\mathrm{N}$

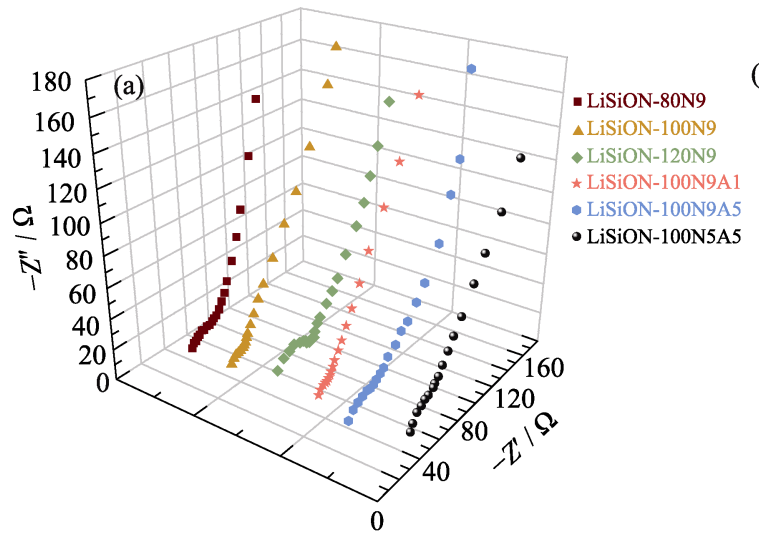

(b)
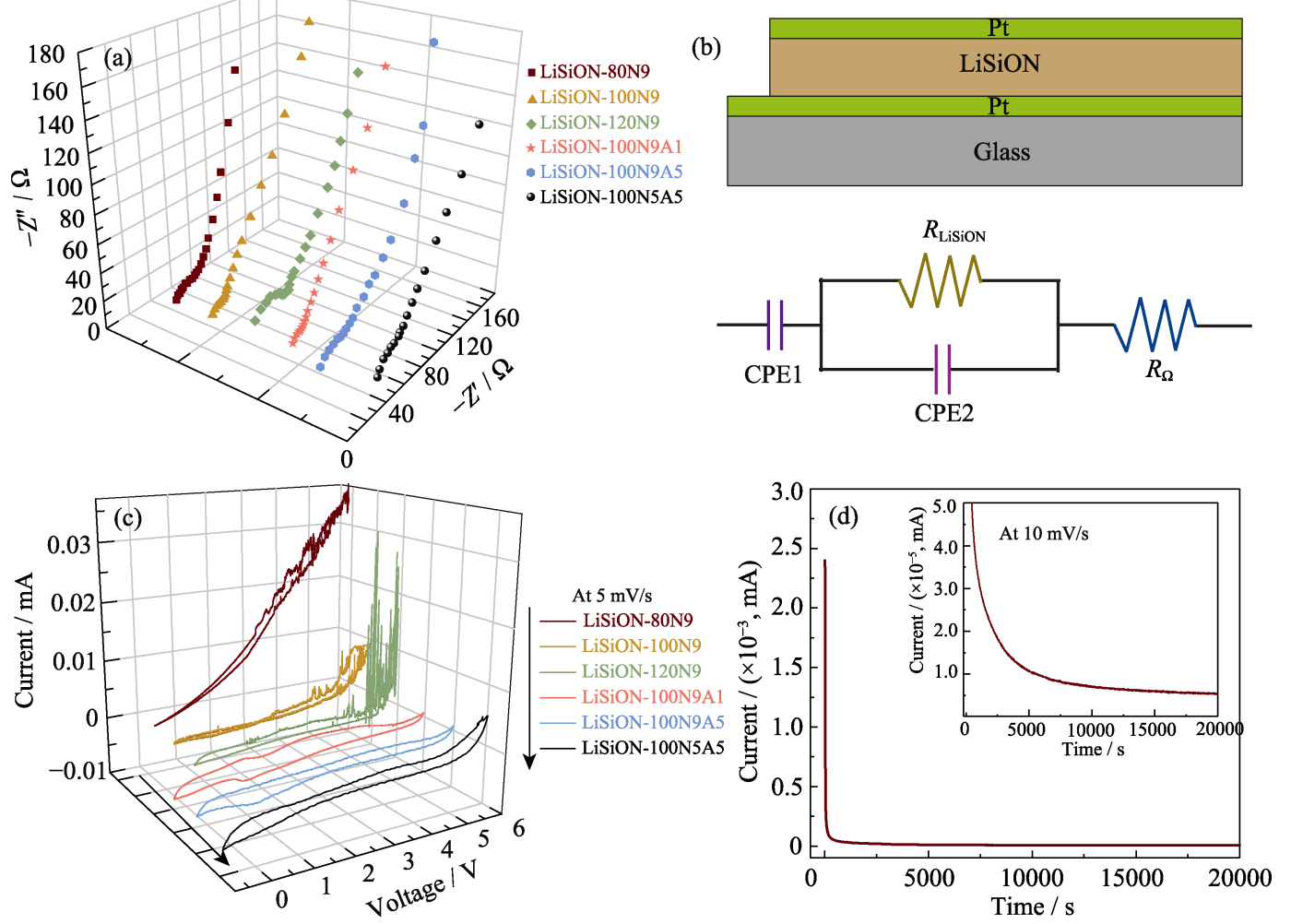

Fig. 3 (a) Electrochemical impedance spectroscopy (EIS) spectra of the LiSiON thin films deposited under different conditions;

(b) Schematic illustration of the $\mathrm{Pt} / \mathrm{LiSiON} / \mathrm{Pt}$ sandwich structure and the corresponding equivalent circuit; (c) CV curves of the LiSiON thin films deposited under different conditions; (d) Chronoamperometry curve of the sample LiSiON-100N9A1 
Table 1 Comparison of lithium ion conductivities and voltage windows of LiSiON thin films deposited under different conditions

\begin{tabular}{lcc}
\hline \multicolumn{1}{c}{ Sample } & $\begin{array}{c}\text { Lithium ion } \\
\text { conductivities } \\
/\left(\times 10^{-6}, \mathrm{~S} \cdot \mathrm{cm}^{-1}\right)\end{array}$ & $\begin{array}{c}\text { Voltage } \\
\text { windows/V }\end{array}$ \\
\hline LiSiON-80N9 & 4.6 & $\sim 2.0$ \\
LiSiON-100N9 & 7.1 & $\sim 3.9$ \\
LiSiON-120N9 & 2.5 & $\sim 4.2$ \\
LiSiON-100N9A1 & 6.3 & $\sim 5.0$ \\
LiSiON-100N9A5 & 3.0 & $\sim 4.6$ \\
LiSiON-100N5A5 & 2.9 & $\sim 5.2$ \\
\hline
\end{tabular}

$\sim 5.2 \mathrm{~V}$, respectively, which are close to that of LiPON electrolyte. Therefore, taken both the ionic conductivity and voltage window into consideration, sample LiSiON100N9A1 was chosen for further investigation and the fabrication of full cell. To explore the lithium ion transference number $\left(\tau_{\mathrm{i}}\right)$ and the electronic conductivity $\left(\sigma_{\mathrm{e}}\right)$ of sample LiSiON-100N9A1, chronoamperometry was further performed at a constant voltage of $10 \mathrm{mV}$ (Fig. 3(d)). The $\tau_{\mathrm{i}}$ can be calculated by Eq. (2).

$$
\tau_{\mathrm{i}}=\left(I_{\mathrm{b}}-I_{\mathrm{e}}\right) / I_{\mathrm{b}}
$$

where $I_{\mathrm{b}}$ is the initial polarization current, and $I_{\mathrm{e}}$ is the steady state current ${ }^{[18]}$. The $\tau_{\mathrm{i}}$ was calculated to be 0.998 , which is close to 1 , indicating that the lithium ions conduction is absolutely dominant in the electrolyte. The $\tau_{\mathrm{i}}$ is determined by a mixed effect of the conduction of ions and electrons ${ }^{[24]}$, which can be expressed by Eq. (3).

$$
\tau_{\mathrm{i}}=\sigma_{\mathrm{i}} /\left(\sigma_{\mathrm{i}}+\sigma_{\mathrm{e}}\right)
$$

Thus, the $\sigma_{\mathrm{e}}$ of the sample LiSiON-100N9A1 is calculated to be $1.26 \times 10^{-8} \mathrm{~S} \cdot \mathrm{cm}^{-1}$, which is negligible compared to its ion conductivity.

To verify the feasibility of the optimized sample LiSiON100N9A1 for TFLB application, $\mathrm{MoO}_{3} / \mathrm{LiSiON} / \mathrm{Li}$ TFLB was further fabricated. The cross-section FESEM image and corresponding EDS mapping images of the $\mathrm{MoO}_{3} / \mathrm{LiSiON} / \mathrm{Li}$ TFLB are shown in Fig. 4(a). As observed, the $\mathrm{MoO}_{3}$ cathode (about $1.1 \mu \mathrm{m}$ in thickness) and the $\mathrm{Li}$ anode are well separated by the LiSiON
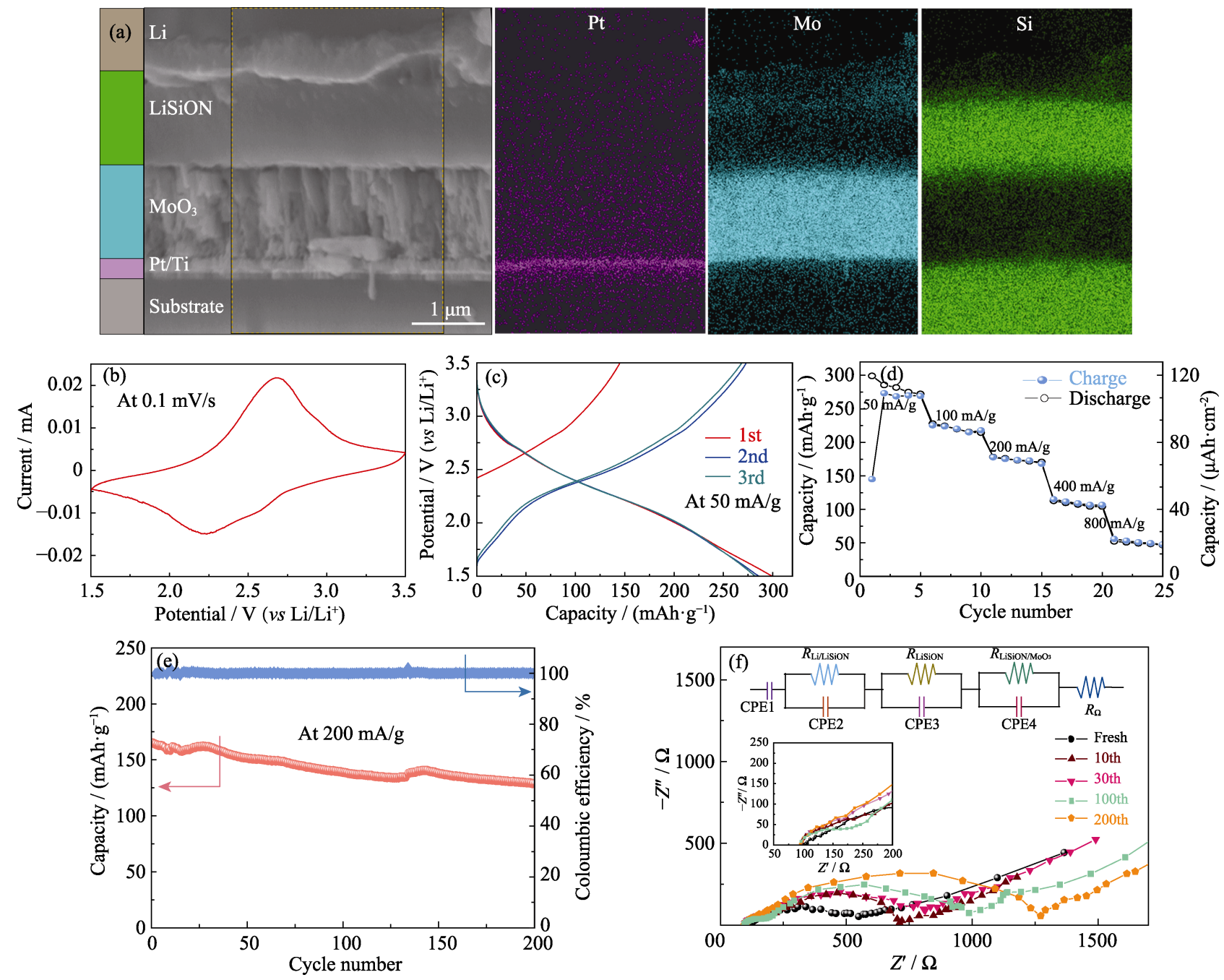

Fig. 4 (a) Cross-section FESEM image and corresponding EDS mapping images of the $\mathrm{MoO}_{3} / \mathrm{LiSiON} / \mathrm{Li}$ TFLB;

(b) Typical CV curve, (c) initial three charge/discharge curves, (d) rate performance, (e) cycle performance, and (f) EIS spectra at different cycle numbers of the $\mathrm{MoO}_{3} / \mathrm{LiSiON} / \mathrm{Li}$ TFLB with sample LiSiON-100N9A1 as electrolyte 
electrolyte, and the LiSiON electrolyte has tight contact interfaces with both the cathode and the anode. Fig. 4(b) displays the typical CV curve of the TFLB at a scan rate of $0.1 \mathrm{mV} \cdot \mathrm{s}^{-1}$ between $1.5-3.5 \mathrm{~V}$, which shows a pair of well-defined redox peaks at around 2.25 and $2.65 \mathrm{~V}$, corresponding to lithium ion insertion into and extraction from the $\mathrm{MoO}_{3}{ }^{[10]}$. Fig. 4(c) depicts the initial 3 galvanostatic charge/discharge curves of the TFLB at a current density of $50 \mathrm{~mA} \cdot \mathrm{g}^{-1}\left(20 \mu \mathrm{A} \cdot \mathrm{cm}^{-2}\right.$, based on the mass of $\mathrm{MoO}_{3}$ film). As observed, the TFLB delivers the initial charge/discharge capacities of $145 / 297 \mathrm{mAh} \cdot \mathrm{g}^{-1}$ $\left(58 / 118.8 \mu \mathrm{Ah} \cdot \mathrm{cm}^{-2}\right)$. After the 2nd cycle, steady cycling behavior with high reversible specific capacity of $282 \mathrm{mAh} \cdot \mathrm{g}^{-1}$ was achieved by the TFLB. The rate performance of the TFLB at various current densities is depicted in Fig. 4(d). The irreversible capacity loss of the TFLB in initial several cycles at low current density can be attributed to irreversible phase transition in the $\mathrm{MoO}_{3}$ derived by lithium insertion ${ }^{[26]}$. Stable discharge capacities of about $219,173,107$, and $50 \mathrm{mAh} \cdot \mathrm{g}^{-1}$ are observed at $100,200,400$, and $800 \mathrm{~mA} \cdot \mathrm{g}^{-1}$, respectively, demonstrating good rate capability. To evaluate the electrochemical stability of the TFLB, cycle performance was further performed at a current density of $200 \mathrm{~mA} \cdot \mathrm{g}^{-1}$ (Fig. 4(e)). The TFLB can retain $78.1 \%$ of its initial discharge capacity after 200 cycles, and the Coulombic efficiency is near $100 \%$ for each cycle, revealing acceptable electrochemical stability of the LiSiON electrolyte. EIS measurements were further carried out at open circuit voltage to investigate the electrolyte/electrode interface in the TFLB at different cycle numbers, and the corresponding Nyquist plots with equivalent circuit are depicted in Fig. 4(f). As observed, the $\mathrm{MoO}_{3} / \mathrm{LiSiON} / \mathrm{Li}$ TFLB shows similar EIS spectrum which consists of two semicircles in the high frequency region at fresh state to that of the $\mathrm{MoO}_{3} / \mathrm{LiPON} / \mathrm{Li}$ TFLB in our previous work ${ }^{[10]}$, indicating that the $\mathrm{Li} / \mathrm{LiSiON}$ interfacial resistance is negligible compared to that of the $\mathrm{LiSiON} / \mathrm{MoO}_{3}$ interface ${ }^{[20]}$. The first small semicircle in the Nyquist plots is attributed to the ionic conduction of $\mathrm{Li}^{+}$ions in LiSiON electrolyte, while the second large semicircle corresponds to the charge transfer process at the $\mathrm{LiSiON} / \mathrm{MoO}_{3}$ interface ${ }^{[27-28]}$. It is noted that the first small semicircle rarely changes during the cycles, indicating the relatively good cyclic stability of the LiSiON electrolyte. However, the second semicircle gradually expands as the cycle number evolves, revealing the increased $\mathrm{LiSiON} / \mathrm{MoO}_{3}$ interfacial resistance during cycling, which could be the main reason for the capacity fading of the TFLB ${ }^{[29]}$. It is worth mentioning that this work successfully adopts the LiSiON electrolyte to construct TFLB and demonstrates the good interfacial contact of $\mathrm{LiSiON}$ with both the $\mathrm{MoO}_{3}$ cathode and the lithium anode for the first time. Moreover, the large specific capacity, good rate capability, and acceptable cycle performance of the $\mathrm{MoO}_{3} / \mathrm{LiSiON} / \mathrm{Li}$ TFLB demonstrate that the LiSiON thin film is well applicable as electrolyte for TFLB.

\section{Conclusions}

In summary, amorphous LiSiON thin film electrolyte was successfully prepared by RF magnetron sputtering using $\mathrm{Li}_{2} \mathrm{SiO}_{3}$ target with $\mathrm{N}_{2} / \mathrm{Ar}$ gas flow. The optimized LiSiON thin film deposited under RF power of $100 \mathrm{~W}$ at the flow of $90 \mathrm{sccm} \mathrm{N}_{2}$ and $10 \mathrm{sccm}$ Ar possesses smooth surface, dense structure, high ion conductivity $\left(6.3 \times 10^{-6} \mathrm{~S} \cdot \mathrm{cm}^{-1}\right)$, and wide voltage window $(5 \mathrm{~V})$, making it a promising electrolyte material for TFLB. More importantly, by using the LiSiON electrolyte, a $\mathrm{MoO}_{3} / \mathrm{LiSiON} / \mathrm{Li}$ TFLB was successfully demonstrated for the first time with high specific capacity $\left(282 \mathrm{mAh} \cdot \mathrm{g}^{-1}\right.$ at $\left.50 \mathrm{~mA} \cdot \mathrm{g}^{-1}\right)$, good rate performance $\left(50 \mathrm{mAh} \cdot \mathrm{g}^{-1}\right.$ at $\left.800 \mathrm{~mA} \cdot \mathrm{g}^{-1}\right)$, and acceptable cycle stability $(78.1 \%$ capacity retention after 200 cycles). This work is expected to bring new opportunities to develop high- performance TFLB by using $\mathrm{Li}_{2} \mathrm{O}-\mathrm{SiO}_{2}$ based thin film electrolyte.

\section{References:}

[1] MOITZHEIM S, PUT B, VEREECKEN P M. Advances in 3D thin-film Li-ion batteries. Advanced Materials Interfaces, 2019, 6(15): 1900805

[2] XIA Q, ZHANG Q, SUN S, et al. Tunnel intergrowth $\mathrm{Li}_{x} \mathrm{MnO}_{2}$ nanosheet arrays as 3D cathode for high-performance all-solidstate thin film lithium microbatteries. Advanced Materials, 2021, 33(5): 2003524.

[3] DENG Y, EAMES C, FLEUTOT B, et al. Enhancing the lithium ion conductivity in lithium superionic conductor (LISICON) solid electrolytes through a mixed polyanion effect. ACS Applied Materials \& Interfaces, 2017, 9(8): 7050-7058.

[4] BATES J B, DUDNEY N J, GRUZALSKI G R, et al. Fabrication and characterization of amorphous lithium electrolyte thin films and rechargeable thin-film batteries. Journal of Power Sources, 1993, 43(1/2/3): 103-110.

[5] BATES J. Electrical properties of amorphous lithium electrolyte thin films. Solid State Ionics, 1992, 53(56): 647-654.

[6] FAMPRIKIS T, GALIPAUD J, CLEMENS O, et al. Composition dependence of ionic conductivity in $\operatorname{LiSiPO}(\mathrm{N})$ thin-film electrolytes for solid-state batteries. ACS Applied Energy Materials, 2019, 2(7): 4782-4791.

[7] DENG Y, EAMES C, CHOTARD J N, et al. Structural and mechanistic insights into fast lithium-ion conduction in $\mathrm{Li}_{4} \mathrm{SiO}_{4}$ $\mathrm{Li}_{3} \mathrm{PO}_{4}$ solid electrolytes. Journal of the American Chemical Society, 2015, 137(28): 9136-9145.

[8] CHEN R, SONG X. The ionic conductivity of solid electrolytes for $\mathrm{Li}_{4+x} \mathrm{M}_{x} \mathrm{Si}_{1-x} \mathrm{O}_{4-y} \mathrm{Li}_{2} \mathrm{O}(\mathrm{M}=\mathrm{Al}, \mathrm{B})$ systems. Journal of the Chinese Chemical Society, 2002, 49: 7-10. 
[9] ADNAN S, MOHAMED N S. Effects of Sn substitution on the properties of $\mathrm{Li}_{4} \mathrm{SiO}_{4}$ ceramic electrolyte. Solid State Ionics, 2014, 262: $559-562$.

[10] SUN S, XIA Q, LIU J, et al. Self-standing oxygen-deficient $\alpha-\mathrm{MoO}_{3-x}$ nanoflake arrays as $3 \mathrm{D}$ cathode for advanced all-solidstate thin film lithium batteries. Journal of Materiomics, 2019, 5(2): 229-236.

[11] DING W, LU W, DENG X, et al. An XPS study on the structure of $\operatorname{SiN}_{x}$ film deposited by microwave ECR magnetron sputtering. Acta Physica Sinica, 2009, 58(6): 4109-4116.

[12] KIM H, KIM Y. Partial nitridation of $\mathrm{Li}_{4} \mathrm{SiO}_{4}$ and ionic conductivity of $\mathrm{Li}_{4.1} \mathrm{SiO}_{3.9} \mathrm{~N}_{0.1}$. Ceramics International, 2018, 44(8): 9058-9062.

[13] MARIKO M, HIDEMASA K ,TOMOYUKI O, et al. Analysis of $\mathrm{SiO}$ anodes for lithium-ion batteries. Journal of The Electrochemical Society, 2005, 152(10): A2089.

[14] FINGERLE M, BUCHHEIT R, SICOLO S, et al. Reaction and space charge layer formation at the $\mathrm{LiCoO}_{2}-\mathrm{LiPON}$ interface: insights on defect formation and ion energy level alignment by a combined surface science-simulation approach. Chemisty Materials, 2017, 29(18): 7675-7685.

[15] WEST W, HOOD Z, ADHIKARI S, et al. Reduction of chargetransfer resistance at the solid electrolyte-electrode interface by pulsed laser deposition of films from a crystalline $\mathrm{Li}_{2} \mathrm{PO}_{2} \mathrm{~N}$ source. Journal of Power Sources, 2016, 312: 116-122.

[16] SICOLO S, FINGERLE M, HAUSBRAND R, et al. Interfacial instability of amorphous LiPON against lithium: a combined density functional theory and spectroscopic study. Journal of Power Sources, 2017, 354: 124-133.

[17] WU F, LIU Y, CHEN R, et al. Preparation and performance of novel Li-Ti-Si-P-O-N thin-film electrolyte for thin-film lithium batteries. Journal of Power Sources, 2009, 189(1): 467-470.

[18] PUT B, VEREECKEN M, MEERSSCHAUT J, et al. Electrical characterization of ultrathin RF-sputtered LiPON layers for nanoscale batteries. ACS Applied Materials \& Interfaces, 2016,
8(11): 7060-7069.

[19] NIINOMI H, MOTOYAMA M, IRIYAMA Y. $\mathrm{Li}^{+}$Conduction in Li-Nb-O films deposited by a Sol-Gel method. Solid State Ionics, 2016, 285: 13-18.

[20] SONG S, LEE K, PARK H. High-performance flexible all-solid-state microbatteries based on solid electrolyte of lithium boron oxynitride. Journal of Power Sources, 2016, 328: 311-317.

[21] OHTSUKA H, OKADA S, YAMAKI J. Solid state battery with $\mathrm{Li}_{2} \mathrm{O}-\mathrm{V}_{2} \mathrm{O}_{5}-\mathrm{SiO}_{2}$ solid electrolyte thin film. Solid State Ionics, 1990 , 40-41: 964-966.

[22] Kalita D, Lee $\mathrm{S}$, Lee $\mathrm{K}$, et al. Ionic conductivity properties of amorphous Li-La-Zr-O solid electrolyte for thin film batteries. Solid State Ionics, 2012, 229: 14-19.

[23] SAKURAI Y, SAKUDA A, HAYASHI A, et al. Preparation of amorphous $\mathrm{Li}_{4} \mathrm{SiO}_{4}-\mathrm{Li}_{3} \mathrm{PO}_{4}$ thin films by pulsed laser deposition for all-solid-state lithium secondary batteries. Solid State Ionics, 2011, 182: 59-63.

[24] TAN G, WU F, LI L, et al. Magnetron sputtering preparation of nitrogen-incorporated lithium-aluminum-titanium phosphate based thin film electrolytes for all-solid-state lithium ion batteries. The Journal of Physical Chemistry C, 2012, 116(5): 3817-3826.

[25] YU X, BATES J B, JELLISON G, et al. A stable thin-film lithium electrolyte: lithium phosphorus oxynitride. Journal of The Electrochemical Society, 1997, 144(2): 524.

[26] KIM H, COOK J, LIN H, et al. Oxygen vacancies enhance pseudocapacitive charge storage properties of $\mathrm{MoO}_{3-x}$. Nature Materials, 2017, 16: 454-460.

[27] SONG H, WANG S, SONG X, et al. Solar-driven all-solid-state lithium-air batteries operating at extreme low temperatures. Energy \& Environmental Science, 2020, 13(4): 1205-1211.

[28] WANG Z, LEE J, XIN H, et al. Effects of cathode electrolyte interfacial (CEI) layer on long term cycling of all-solid-state thin-film batteries. Journal of Power Sources, 2016, 324: 342-348.

[29] QIAO Y, DENG H, HE P, et al. A $500 \mathrm{Wh} / \mathrm{kg}$ lithium-metal cell based on anionic redox. Joule, 2020, 4(6): 1311-1323.

\title{
非晶 LiSiON 薄膜电解质的全固态薄膜锂电池性能
}

\author{
夏求应, 孙硕, 备 峰, 徐璟, 夏晖 \\ (南京理工大学 材料科学与工程学院, 南京 210094)
}

摘 要: 全固态薄膜锂电池(TFLB)是理想的微电子系统电源。目前报道的固态非晶电解质存在离子电导率偏低的问

题, 限制了 TFLB 性能的提升。本工作采用磁控贼射法制备了一种新型非晶锂硅氧氮(LiSiON)薄膜用作 TFLB 的固 态电解质。结果表明, 优化制备条件后的 LiSiON 薄膜具有 $6.3 \times 10^{-6} \mathrm{~S} \cdot \mathrm{cm}^{-1}$ 的高离子电导率以及超过 $5 \mathrm{~V}$ 的宽电压 窗口, 适合作为 TFLB 的电解质。在 LiSiON 薄膜电解质的基础上, 本工作构建了 $\mathrm{MoO}_{3} / \mathrm{LiSiON} / \mathrm{Li}$ TFLB 并获得高 的比容量 $\left(50 \mathrm{~mA} \cdot \mathrm{g}^{-1}\right.$ 下 $\left.282 \mathrm{mAh} \cdot \mathrm{g}^{-1}\right)$ 、良好的倍率性能 $\left(800 \mathrm{~mA} \cdot \mathrm{g}^{-1}\right.$ 下 $\left.50 \mathrm{mAh} \cdot \mathrm{g}^{-1}\right)$ 和可观的循环寿命 $(200$ 次循环后 容量保持率为 $78.1 \%$ ), 验证了该电解质在薄膜电池中应用的可行性。

关 键 词: LiSiON; 薄膜电解质; 全固态锂电池; 薄膜电池

中图分类号: TQ174 文献标志码: A 